\title{
ACRL 1981/1982 Budget
}

ACRL Summary Budgets

\begin{tabular}{|c|c|c|}
\hline \multicolumn{3}{|c|}{ ACRL } \\
\hline & $1980 / 81$ & $1981 / 82$ \\
\hline Revenue* & $\$ 333,881$ & $\$ 769,494$ \\
\hline Expense & 391,922 & 768,920 \\
\hline & $(58,041)$ & 574 \\
\hline $\begin{array}{l}\text { Amount carried } \\
\text { forward }\end{array}$ & 74,952 & 78,746 \\
\hline Balance & $\$ 16,911$ & $\$ 79,320$ \\
\hline \multicolumn{3}{|c|}{ Choice } \\
\hline Revenue & $\$ 708,814$ & $\$ 810,580$ \\
\hline Expense & 698,749 & 810,570 \\
\hline \multirow[b]{2}{*}{$\begin{array}{l}\text { Amount carried } \\
\text { forward** }\end{array}$} & 10,065 & 10 \\
\hline & 36,171 & 36,000 \\
\hline Balance & $\$ 46,236$ & $\$ 36,010$ \\
\hline
\end{tabular}

** Estimates provided by the ALA Controller.

\section{Highlights}

At the annual meeting in San Francisco, the ACRL Board of Directors adopted the 1981/82 ACRL budget, with the provision that this budget would be used only if the membership dues increase ballot passed. The membership did subsequently adopt the increase in dues. Highlights of the budget include:

- An increase in membership dues income of $\$ 70,000$.

- A decrease in the allocation to CdRL News of $\$ 21,000$ as a result of increases in C $d R L$ News revenue.

- An increase in College and Research Libraries revenue as a result of raising journal subscription rates for non-members.

- An increase in revenues from the ACRL continuing education program, reflecting the growth of that program.

- The continuation of funding for the Bibliographic Instruction Liaison Project.

- The addition of a staff position to support the ACRL national conference activity, preconferences, sections and committees.

- A $\$ 14,000$ increase in support to committees.

- A $\$ 13,212$ increase in support of section activities.

- A $\$ 2,611$ increase in support to chapters.

- The allocation of a $\$ 30,000$ operational reserve for the Association.
- The budget for a proposal, subsequently funded by the National Endowment for the Humanities, was approved. This grant provides funding for two workshops on "Programming in the Humanities."

- A cost-of-living increase of $6 \%$ to staff. This increase is an ALA-wide staff cost-of-living increase.

\section{Income and Expenditures}

The pie chart on the next page shows the major projected sources of revenue and expenditures for ACRL, excluding Choice, the Minneapolis Conference (other than allocations), and the NEH grant. The latter two are excluded since they are not annual events and would make comparisons with last year's budget difficult (see C\&RL News, October 1980).

A compilation indicating where ACRL funds (including staff time) are specifically derived from and expanded is shown on the next page. Comparisons with the previous year are also shown.

This compilation reflects ACRL's continuing move toward program budgeting. This year it has been refined to show section preconferences and the Association's continuing education program as separate activities.

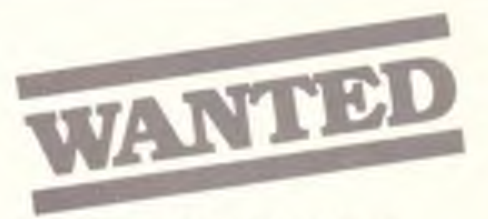

We are interested in purchasing

PERIODICAL SETS

MONOGRAPHS IN SERIES BOOK COLLECTIONS

Please contact or send lists to:

ABRAHAMS MAGAZINE SERVICE, INC.

56 East 13 th Street, New York, N.Y. 10003 (212) $777-4700$ TWX 710-581-2302 
With the increase in the membership dues, the trend towards a shrinking proportion of revenue coming from that source has been halted for this year. The impact of the dues increase on membership retention is hard to predict. This past year ACRL membership increased by 5 per cent.

Inflation continues to increase the support needed for those programs which do not directly produce revenues, such as the Board, sections, committees, discussion groups, and chapters. The support of these programs is essential for the continuing renewal and growth of the Association.

The Budget and Finance Committee is examining questions related to how fixed costs will be charged, and to which programs should overhead costs be assessed in determining the long-term viability of the programs. The committee expects to make recommendations to the Board on these issues in the next year.

\section{INCOME}

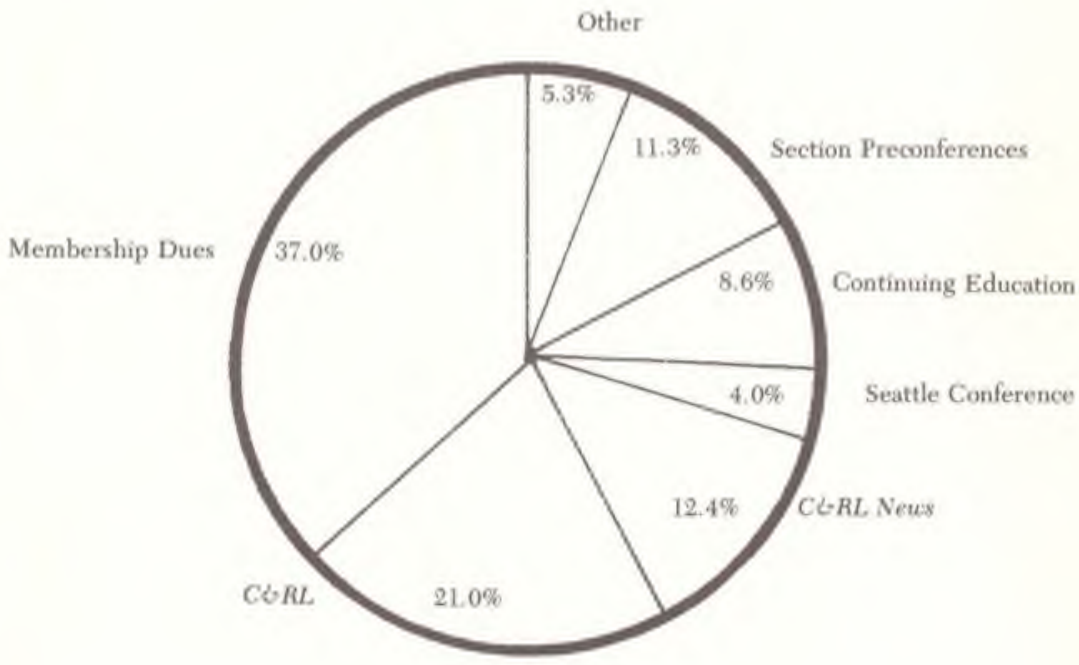

EXPENSE

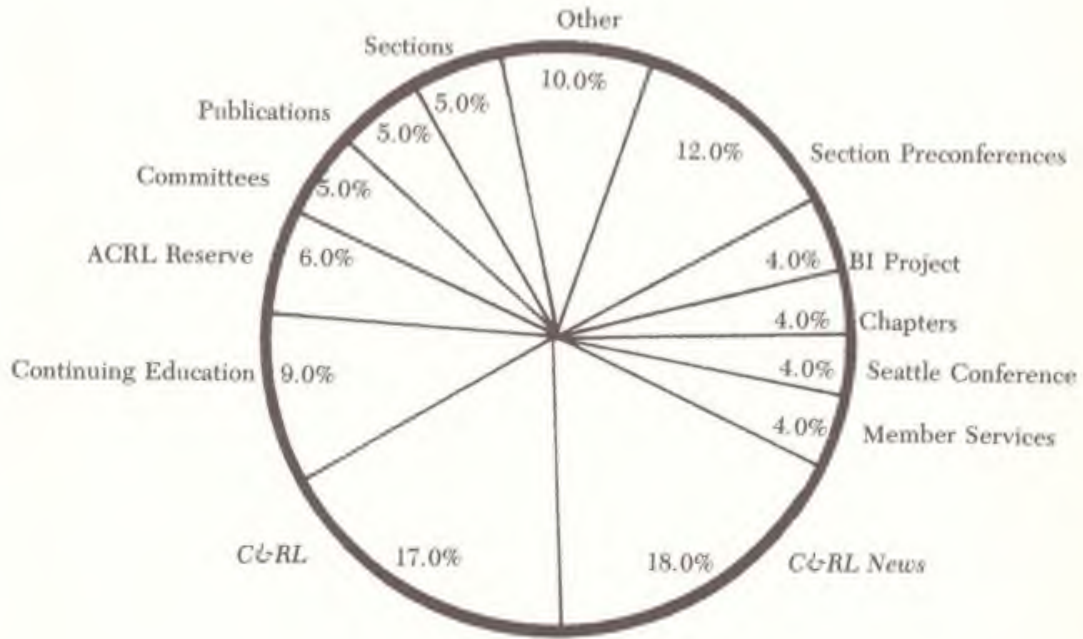


INCOME

\begin{tabular}{|c|c|c|c|c|c|}
\hline Activity & $1980 / 81$ & $1981 / 82$ & Difference & $\begin{array}{c}\% \text { of } \\
1980 / 81\end{array}$ & $\begin{array}{c}\% \text { of } \\
1981 / 82\end{array}$ \\
\hline Membership & $\$ 121,445$ & $\$ 192,500$ & $\$ 71,055$ & 36.4 & 37.4 \\
\hline$C \triangleleft R L$ & 88,814 & 108,078 & 19,264 & 26.6 & 21.0 \\
\hline CURL News* & 37,448 & 64,023 & 26,575 & 11.2 & 12.4 \\
\hline Preconferences & 37,710 & 58,075 & $20,365)$ & & 11.3 \\
\hline Continuing Education & 1,875 & 44,600 & 36,725 & 11.9 & 8.6 \\
\hline Seattle Allocation & - & 20,622 & 20,622 & - & 4.0 \\
\hline Choice Allocation & 5,246 & 8,300 & 3,054 & 1.6 & 1.6 \\
\hline Publications & 7,100 & 7,500 & 400 & 2.1 & 1.4 \\
\hline Fast Job Listing Service & - & 4,100 & 4,100 & - & .8 \\
\hline Jobline & - & 4,000 & 4,000 & - & .8 \\
\hline Minneapolis Conf. Allocation & 33,143 & 1,857 & $(31,286)$ & 9.9 & .3 \\
\hline ACRL 100 Libraries & - & 800 & 800 & - & 2 \\
\hline Contributions \& Gifts & 1,100 & 800 & $(300)$ & .3 & 2 \\
\hline $\begin{array}{l}\text { Minneapolis Conference } \\
\text { NEH Project }\end{array}$ & $\begin{array}{c}333,881^{*} \\
- \\
-\end{array}$ & $\begin{array}{r}515,255^{*} \\
189,690 \\
64,549\end{array}$ & & $100 \%$ & $100 \%$ \\
\hline TOTAL & $\$ 333,881$ & $\$ 769,494$ & & & \\
\hline
\end{tabular}

*This figure does not include the allocation of $\$ 40,892$ to C $-R L$ News in $1980 / 81$ and $\$ 19,741$ in 1981/82. These figures represent a transfer of ACRL funds within the ACRL budgets.

\section{EXPENDITURES}

\begin{tabular}{|c|c|c|c|c|c|}
\hline Activity & $1980 / 81$ & $1981 / 82$ & Difference & $1980 / 81$ & $1981 / 82$ \\
\hline CURL News & $\$ 102,309$ & $\$ 91,511$ & $\$(10,798)$ & 26.1 & 17.8 \\
\hline$C \& R L$ & 85,441 & 85,683 & 242 & 21.8 & 16.6 \\
\hline Preconferences? & 85,473 & 60,075 & 19,491 & 21.8 & 11.7 \\
\hline $\begin{array}{l}\text { CE Program } \\
\text { ACRL Reserve }\end{array}$ & - & $\begin{array}{l}44,889 \\
30,000\end{array}$ & 30,000 & - & $\begin{array}{l}8.7 \\
5.8\end{array}$ \\
\hline Committees & 12,486 & 26,452 & 13,966 & 3.2 & 5.2 \\
\hline Publications & 7,638 & 25,436 & 17,798 & 1.9 & 4.9 \\
\hline Sections & 10,013 & 23,225 & 13.212 & 2.6 & 4.5 \\
\hline Member Services & 13,680 & 20,294 & 6,614 & 3.5 & 3.9 \\
\hline Seattle Conference & 2,388 & 20,622 & 18,234 & 6 & 4.0 \\
\hline BI Project & - & 18,645 & 18,645 & - & 3.6 \\
\hline Chapters & 15,905 & 18,516 & 2,611 & 4.1 & 3.6 \\
\hline Advisory & 7,126 & 13,056 & 5,930 & 1.8 & 2.5 \\
\hline Choice & 4,217 & 10,659 & 6,442 & 1.1 & 2.1 \\
\hline Minneapolis Conf. Allocation & 33,143 & 9,000 & $(24,143)$ & 8.5 & 1.8 \\
\hline Fast Job Listing Service & 4,039 & 6,443 & 2,404 & 1.0 & 1.3 \\
\hline Jobline & - & 3,496 & 3,496 & - & .7 \\
\hline Discussion Groups & 428 & 3,146 & 2,718 & 1 & .6 \\
\hline ACRL 100 & 1,786 & 1,681 & (105) & .5 & .3 \\
\hline University Library Statistics & 3,639 & - & $(3,639)$ & .9 & 一 \\
\hline SCMAI & 1,236 & - & $(1,236)$ & .3 & - \\
\hline Other & 975 & 1,852 & 877 & 2 & .4 \\
\hline & 391,922 & 514,681 & 122,759 & $100 \%$ & $100 \%$ \\
\hline $\begin{array}{l}\text { Minneapolis Conference } \\
\text { NEH Project }\end{array}$ & & 189,690 & 189,690 & & \\
\hline NEH Project & & 64,549 & 64,549 & & \\
\hline TOTAL & $\$ 391,922$ & $\$ 768,920$ & $\$ 376,998$ & & \\
\hline
\end{tabular}

The Minneapolis conference and NEH project budgets are excluded from the percentage calculations in both tables since they would significantly distort comparisons made with the previous year. 